\title{
Spatial analysis of water quality of the Karra River, Hetauda, Nepal
}

\section{Sadhana Pradhanang (Kayastha)}

Department of Environmental Science, Tri-Chandra Campus,

Tribhuvan University, Kathmandu, Nepal

\begin{abstract}
The assessment of water quality of Karra River in Hetauda, Nepal was carried out by determining the changes in the concentration levels of eight physico-chemical parameters ( $\mathrm{H}$, Electric conductivity (EC), bicarbonate, dissolved oxygen (DO), silica, chemical oxygen demand (COD), phosphate and nitrate). The samples were collected from upstream, industrial belt and downstream of the Karra River. The Karra River is the dumping ground for industrial effluents of Hetauda industrial district (HID). On analysis, the concentrations of most of the physico-chemicals parameters were found to be above the prescribed limits for industrial wastewater into inland surface waters. Dissolved Oxygen was found to be in the range of 0.49-8.47 $\mathrm{mg} / \mathrm{L}$ while COD, nitrate and phosphate were recorded in the range of $8.3-367 \mathrm{mg} / \mathrm{L}, 0.35-78.22 \mathrm{mg} / \mathrm{L}$ and 0.01-1.64 $\mathrm{mg} / \mathrm{L}$, respectively. Concentrations of most of these parameters were within the prescribed limits in the samples collected from upstream and downstream, revealing the river still in good condition at these points indicating less human interference at the head water region and good self-purification capacity at downstream. However the concentrations of the pollutants' parameters are higher at the sample points just after effluent discharge.
\end{abstract}

Keywords: Karra, River, industrial effluent, Hetauda industrial district, pollution.

\section{INTRODUCTION}

Water pollution is the most serious environmental problem in Nepal. It's mainly due to direct disposal of solid and liquid waste on land and surface water. Rivers play a major role in carrying and assimilating the industrial and municipal wastewater, and surface runoff from the agricultural lands. River water quality especially passing through the industry and urban areas is poor due to the direct disposal of industrial effluents and other wastes into the river in urban area (Emonger et al., 2005 and Ugochukwu, 2004). The seasonal variations in rainfall, surface runoff, stream flow and groundwater flow, have strong effects on river discharge and subsequently on the concentration of pollutants in river water (Vega et al., 1998). The quality of surface water depends upon natural processes (such as precipitation rate, weathering processes and soil erosion) as well as anthropogenic effects (such as urban, industrial and agricultural activities and the

Email: sadhana.pradhanang@gmail.com 
human exploitation of water resources) (Liao et al., 2007; Nouri et al., 2008). The contribution of untreated waste water discharged into surface water bodies has a negative impact not only on the aquatic life but also affected the self- purification property of the water body. The Information on water quality and pollution sources is important for the implementation of sustainable water-use management strategies (Sarkar et al., 2007; Zhou et al., 2000). Studies investigating the spatial variability of water quality have reported that water quality issues, such as eutrophication, are highly dependent on land use patterns and influence from industrial and municipality effluent (Zhang et al., 2007). Excessive release of nitrogen and phosphorus may enter water bodies such as lakes, rivers and lead to undesirable eutrophication of surface waters, which is the most widespread problem to water environment quality around the world (Carpenter et al., 1998), resulting in serious algal blooms, oxygen depletion and bringing about widespread degradation of freshwater ecosystems (Smith et al., 1999). Nutrient (N and $\mathrm{P})$ enrichment in water bodies can alter water body metabolic activity (Peterson et al., 1985) and finally have knock on effects on the whole food-chain (Peterson et al., 1985). The study of physico- chemical composition of river water is important for determining pollution level of the rivers. In view of this an attempt was made to analyze the physico- chemical parameters of the Karra River. In this study, the Karra River was selected for water quality evaluation where effluent of untreated wastewater of Hetauda industrial district (HID) was observed. The objectives of this study were to (1) reveal the spatial variabilities in water quality and (2) identify the main pollutants sources of water quality. The Karra River is a tributary of the Rapti River, which is an environmentally significant water source area.

\section{MATERIALS AND METHODS}

\section{Area of Study}

The Karra River is located at Hetauda, Nepal. Hetauda lies in Makawanpur district, Narayani zone of the Central Development Region of Nepal between longitudes $85^{\circ}$ to $85^{\circ} 04^{\prime} 30^{\prime \prime}$ East and latitudes $27^{\circ} 24^{\prime} 30^{\prime \prime}$ to $27^{\circ} 30^{\prime}$ North at a height of $390 \mathrm{~m}$ from the mean sea level. The city is enclosed by three rivers, the Rapti to the west, the Samari to the north and the Karra to the south. The Karra River is perennial flow and originates from North-eastern Siwalik Hill and flows towards west to join with the Rapti River, near Hetauda city. Hetauda city is covered by forest, agricultural land, residential area, and industrial area.

The Hetauda Industrial District (HID) is the largest industrial zone in Nepal with an area 145ha. The natural waste stabilization treatment plant at HID was built in 2002-03 under financial and technical assistance of the Government of Denmark. Among 45 operating industries, the waste generated out of 22 industries is being treated in the treatment plant, whereas other industries discharge their waste directly into the Karra River. Major industries in the HID are leather, soap, chemical, dairy, slaughterhouse, vegetable ghee, paint, toothpaste, wood preventives and breweries.

\section{Water sample Collection}

Water samples were collected from sixteen different locations along the Karra River during winter season (December- February, 2006). The samples collected from its upstream (US1- US2), industrial belt (IB1-IB12) and downstream portions (DS1-DS2) of the Karra River. Water sample were taken in triplicate and mixed to get composite samples for each sites. All the surface water samples were collected in pre-cleaned high grade polypropylene bottles 
by following the method as described by APHA (1998). All waters samples were then kept in a cool box at $4^{\circ} \mathrm{C}$ and brought to the laboratory for chemical analysis.

\section{Analysis and preservation}

The $\mathrm{pH}$ value, dissolved oxygen (DO) and electrical conductivity (EC) were measured immediately on spot using portable field equipment's. The $\mathrm{pH}$ was measured using multi component analyzer (Handy lab pH11, D55014 Mainz, Germany) after calibration with standard buffer solutions of 4.0, and $7.0 \mathrm{pH}$. The dissolved oxygen of water samples were determined in-situ by using multi component analyzer (Oxyguard handy Polaris portable DO meter, H01P (Denmark). Conductivity was measured in micro-Siemens/cm $(\mu \mathrm{S} / \mathrm{cm})$ using Eutech (ECTestr11, Singapore).

Water samples for nitrate and phosphate were filtered through 0.45 micron filter paper (Whatman nylon membrane filters, cat. no 7404-002). For COD, water samples were preserved immediately (after sampling) with sulphuric acid to $\mathrm{pH}<2.0$. The solutions were prepared using AR grade compounds with deionized water (Milli-Q specific resistivity18 M' $\Omega$, DQ3 UV, Millipore, India). Glassware and plastic bottles used during analytical procedure were previously soaked in $20 \%$ (v/v) high purity nitric acid for 24 hours and rinsed thoroughly with deionized water with resistivity $18 \mathrm{M} \Omega$.

\section{Analytical methods}

The bicarbonate of water sample was determined following the potentiometric titration method (APHA, 1998). The dissolved silica content was determined by the Molybdo-silicate method (APHA, 1998). The COD in waste water samples was determined by reflux method (APHA, 1998) whereas nitrate and phosphate were analyzed using Ion Chromatograph (Dionex ICS - 3000 DC). All the experiments were carried out in triplicate. The results were reproducible within error limit $\pm 3 \%$ error limit.

\section{Statistical analyses}

Pearson correlation coefficients were computed in order to understand the association and relationship of different physical and chemical parameters of the Karra River. Pearson correlation matrix was calculated by using SYSTAT-12 software for eight different physicochemical parameters such as $\mathrm{pH}$, Electric conductivity (EC), bicarbonate, dissolved oxygen (DO), silica, chemical oxygen demand (COD), phosphate and nitrate. The same parameters were analysed by factor analysis (varimax rotation) using SYSTAT12 and two factors were extracted.

\section{RESULTS AND DISCUSSION}

The rapid development of urban economy, human settlements and industrial development has created severe pollution loads in surface water bodies in urban area (CBS 2002). In this study, $\mathrm{pH}$ has been found to be varying from 7.8 to 8.5 at different sampling sites which indicate moderately alkaline water of Karra River (Table 1). Higher $\mathrm{pH}$ at some sites could be due to bicarbonate and carbonate of calcium and magnesium in water (Begum et al., 2009). The main source of such chemicals should be industrial effluent. This suggests that effluents discharge from this point source is not adequately treated to take care of the effect of the discharge on the $\mathrm{pH}$. Conductivity gives information about the concentration of dissolved salts which varied from 111 to 149 $\mu \mathrm{S} / \mathrm{cm}$ (upstream) and 201 to $538 \mu \mathrm{S} / \mathrm{cm}$ in the industrial belt (Table1). Higher conductivity at site IB 10 and IB11 indicates the mixing 
of industrial waste from WWTP in the river and lower conductivity in downstream (DS1 and DS2) which could be dilution effect that resulted from the confluence of the Rapti River

DO is the key parameter for protecting aquatic life since most of the fish species cannot survive when DO content is less than $3 \mathrm{mg} / \mathrm{L}$ (Novotny, 2002). As dissolved oxygen levels in water drops below $5 \mathrm{mg} / \mathrm{L}$, aquatic life is put under stress and, the lower the concentration, the greater the stress on aquatic animals (APHA, 1998). The DO is one of the potential indicators of river ecosystem (Kennel et al., 2007). The DO fluctuation along the river is shown in Figure 1a. In the present study, DO at upstream sites (US1 and US2) varied from 8.36 to 8.47 $\mathrm{mg} / \mathrm{L}$ with mean value of $8.41 \mathrm{mg} / \mathrm{L}$. The concentration of DO was found to be higher i.e. above acceptable in the upstream of the Karra River whereas in the industrial belt the lowest value was observed to be $0.47 \mathrm{mg} / \mathrm{L}$ and 0.71 $\mathrm{mg} / \mathrm{L}$ at the location IB8 and IB9, respectively indicating anoxic conditions in the river. It is

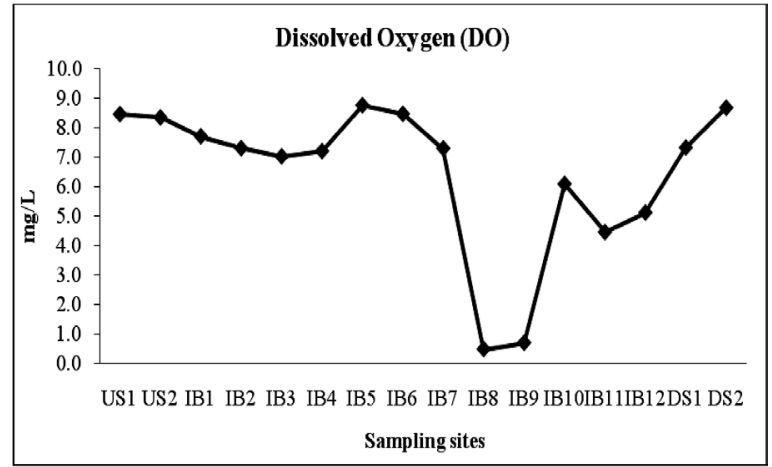

Figure 1a: Spatial variations of dissolved oxygen

clear that the industries were discharging high oxygen demanding waste into the river. The quality of the water in term of DO content is always of primary importance because at the industrial effluent discharge points in river, DO concentration is required for aerobic oxidation of the waste (Mukherjee et al., 1993). The DO levels found to be higher i.e above acceptable level in downstream which may be due to natural self-purification capacity of the river and there was not observed any other effluent discharged into the sections of the river.

Table 1: Physico-chemical characteristics of the Karra River, Hetauda, Nepal.

(mean \pm S.D.) $n=3$

\begin{tabular}{lccccc}
\hline \multicolumn{1}{c}{$\begin{array}{c}\text { Sampling } \\
\text { site }\end{array}$} & $\mathrm{pH}$ & $\mathrm{EC}(\mu \mathrm{S} / \mathrm{cm})$ & $\begin{array}{c}\text { Bicarbonate } \\
(\mathrm{mg} / \mathrm{L})\end{array}$ & Silica $(\mathrm{mg} / \mathrm{L})$ & $\begin{array}{c}\text { Nitrate }\left(\mathrm{NO}_{3}\right. \\
-\mathrm{N} \mathrm{mg} / \mathrm{L})\end{array}$ \\
\hline S1 & $8.00 \pm 0.06$ & $111.17 \pm 6.35$ & $35.50 \pm 0.31$ & $8.80 \pm 0.45$ & $0.35 \pm 0.01$ \\
US2 & $7.8 \pm 0.04$ & $149.94 \pm 5.45$ & $40.80 \pm 1.34$ & $6.63 \pm 0.89$ & $5.82 \pm 0.53$ \\
IB1 & $8.0 \pm 0.01$ & $250.67 \pm 7.30$ & $38.50 \pm 0.58$ & $9.28 \pm 2.81$ & $0.38 \pm 0.01$ \\
IB2 & $8.20 \pm 0.05$ & $201.00 \pm 8.30$ & $47.98 \pm 0.67$ & $7.29 \pm 1.98$ & $0.41 \pm 0.02$ \\
IB3 & $7.50 \pm 0.09$ & $299.73 \pm 25.45$ & $46.80 \pm 0.23$ & $10.83 \pm 0.88$ & $0.44 \pm 0.03$ \\
IB4 & $7.40 \pm 0.05$ & $251.00 \pm 14.23$ & $48.50 \pm 0.30$ & $15.85 \pm 0.78$ & $1.67 \pm 0.02$ \\
IB5 & $8.40 \pm 0.15$ & $302.00 \pm 26.41$ & $140.20 \pm 6.92$ & $17.78 \pm 1.78$ & $2.32 \pm 0.14$ \\
IB6 & $8.90 \pm 0.08$ & $405.33 \pm 15.89$ & $98.45 \pm 5.67$ & $14.37 \pm 0.87$ & $0.75 \pm 0.02$ \\
IB7 & $8.10 \pm 0.03$ & $324.33 \pm 13.45$ & $88.50 \pm 2.46$ & $14.04 \pm 0.79$ & $0.73 \pm 0.04$ \\
IB8 & $7.70 \pm 0.2$ & $451.30 \pm 34.30$ & $250.65 \pm 4.98$ & $29.27 \pm 4.70$ & $78.22 \pm 4.83$ \\
IB9 & $7.70 \pm 0.12$ & $501.67 \pm 15.40$ & $165.00 \pm 3.82$ & $19.06 \pm 1.10$ & $49.94 \pm 3.23$ \\
IB10 & $7.70 \pm 0.23$ & $523.67 \pm 25.29$ & $75.45 \pm 5.87$ & $16.65 \pm 0.82$ & $0.67 \pm 0.02$ \\
IB11 & $7.90 \pm 0.21$ & $538.33 \pm 24.34$ & $300.0 \pm 8.56$ & $16.54 \pm 0.67$ & $6.30 \pm 0.43$ \\
IB12 & $7.90 \pm 0.05$ & $405.00 \pm 27.30$ & $224.50 \pm 3.78$ & $17.76 \pm 1.71$ & $6.54 \pm 0.67$ \\
DS1 & $7.50 \pm 0.01$ & $254.27 \pm 11.40$ & $200.0 \pm 3.78$ & $14.05 \pm 1.86$ & $0.16 \pm 0.01$ \\
DS2 & $8.50 \pm 0.02$ & $350.97 \pm 12.30$ & $150.0 \pm 1.56$ & $10.90 \pm 1.23$ & $0.32 \pm 0.02$ \\
\hline
\end{tabular}


Chemical oxidation demand (COD) is one of the important parameter of water indicating the health scenario of fresh water bodies. High values of COD indicate water pollution, which linked to sewage effluents discharged from industry or agricultural practice (Bellos and Sawidis, 2005). The COD varied from $8.3 \mathrm{mg} / \mathrm{L}$ to $367 \mathrm{mg} / \mathrm{L}$ at different sampling locations of the Karra River (Figure 1b). The maximum mean of COD was at site IB8, followed by IB5 (188 mg/L), IB7 (164 mg/L), IB9 (152 $\mathrm{mg} / \mathrm{L})$ and IB11 (132 $\mathrm{mg} / \mathrm{L})$ which indicates wastewater contamination and organic pollution from treated and untreated effluent.

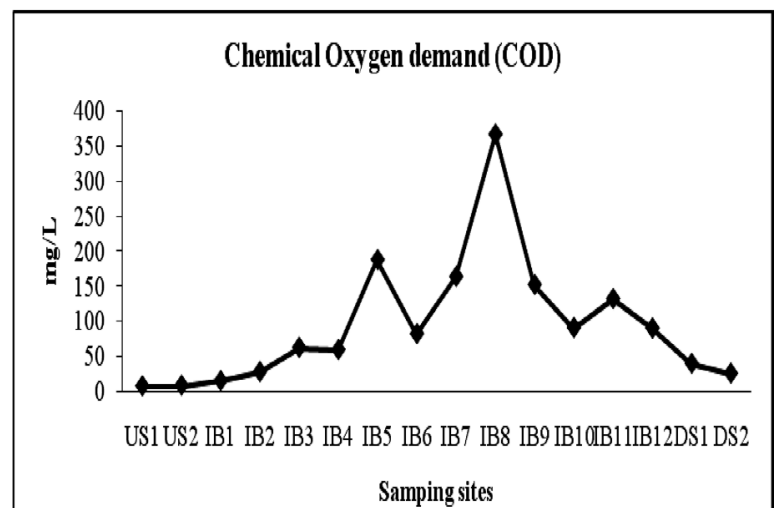

Figure 1b: Spatial variations of chemical oxygen demand

Dissolved silica in river water acts as an important nutrient for the growth of aquatic organisms especially diatoms. The higher concentration of silica at the site IB8 (Table 1) was indicative of regular effluent discharge from soap industry into Karra River. Detergents contain significant amounts of sodium metasilicate which is readily dissolved in water forming dissolved silica. Further down stream, along the river, silica concentration has been found to be low.

The alkalinity of various surface waters is primarily a function of carbonate, bicarbonate and hydroxide (APHA, 1998). The concentration of $\mathrm{HCO}_{3}$ from upstream (US1-US2) varied from 35.5 to $40.80 \mathrm{mg} / \mathrm{L}$ (Table 1 ). In industrial belt, $\mathrm{HCO} 3$ varied from 38.5 to $300 \mathrm{mg} / \mathrm{L}$ (Table 1 ) and in the downstream, $\mathrm{HCO}_{3}$ was found to be varying from 150 to $200 \mathrm{mg} / \mathrm{L}$.

Nitrate is essential for plant growth and is often added to soil to improve agriculture productivity. Agricultural runoff and sewer waste are the main source for nitrate phosphate contamination in the river. In the present study, the concentration of nitrate has been found to be varied from 0.35 to $5.82 \mathrm{mg} / \mathrm{L}$ in the upstream of the river (Table 1). The higher concentration of nitrate at these sites may be from the nonpoint sources like fertilizer use in agriculture land. In the industrial belt (IB1-IB12), the concentration of nitrate fluctuated between 0.38 to $78.22 \mathrm{mg} / \mathrm{L}$ with highest concentration $(78.22 \mathrm{mg} / \mathrm{L})$ recorded at the site IB8 where continuous flowing of treated and untreated effluent from WWTP, HID and may be from non-point sources. The Nitrate concentration from upstream and downstream was found to be lower where the impacts of non-point sources are observed whereas in industrial belt concentration of nitrate was found to be higher due to both point source i.e. industrial waste from HID and non-point sources.

Phosphorus is essential to the growth of organisms and can limit the primary productivity of an aquatic ecosystem (APHA, 1998). The main concern is the growth of algae; some organisms like the blue green algae, can produce toxins as a product of their photosynthesis. The natural background levels of PO4 -P in riverine water bodies usually range from 0.005 to 0.05

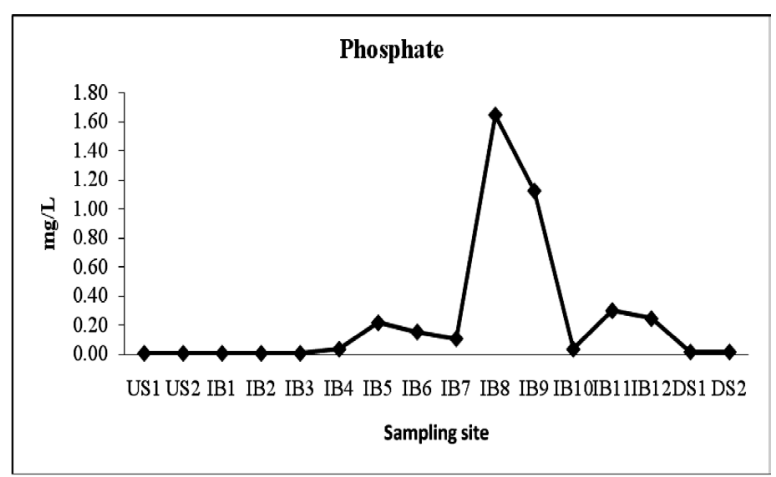

Figure 1c: Spatial variations of phosphate 
$\mathrm{mg} / \mathrm{L}$ (Dunne and Leopold, 1978). In this study, the phosphate from upstream (US1-US2) and downstream (DS1-DS2) was found to be low (Figure 1c). In the industrial belt, phosphate has been found to be quite high at sites IB5 (0.22 $\mathrm{mg} / \mathrm{L})$, IB8 (1.64 mg/L) and IB9 (1.12 mg/L). Higher concentration of phosphate may be due to direct release of effluent from soap industry into the Karra River.

Correlation matrix between different physicochemical parameters is presented in Table2. Correlation was computed in order to understand the association and relationship of physical and chemical parameters. A good correlation was observed between some important water quality parameters of river Karra. The highly significant positive correlation suggests the possibility of common sources which are anthropogenic (Fernandez, et al., 1994). EC of the Karra River water, showed statistically highly significant ( $\mathrm{p}$ $<0.01$ ) correlation with number of variables: silica $(r=0.69)$, bicarbonate $(r=0.66)$, EC showed statistically significant $(\mathrm{p}<0.05)$ correlation with following variables: COD and, phosphate. Highly negative significant correlations of EC have been found with DO $(\mathrm{r}=-0.65)$ (Table 2). Dissolve oxygen does not have strong positive correlation with any other parameters (Table 2). COD of the river water has been found to bear highly significant $(\mathrm{p}<$ $0.01)$ correlation with silica $(\mathrm{r}=0.90)$, nitrate $(\mathrm{r}=0.79)$, and phosphate $(\mathrm{r}=0.84)$, whereas statistically significant $(\mathrm{p}<0.05)$ correlation has been noticed with bicarbonate. Silica showed highly significant correlation $(r=0.69$, 0.68 , and 0.76 , respectively) with bicarbonate, nitrate and phosphate, respectively, and moderate correlations with phosphate, $(\mathrm{r}=$ 0.58). Similarly, nitrate has exhibited highly significant $(\mathrm{p}<0.01)$ correlation with phosphate (Table 2). Table 2 shows the correlation matrix for physico-chemical parameters with significant correlation being indicated by bold type. Inter-element correlations were further investigated by factor analysis (Table 3). This was done in order to obtain an overview of the data and possible sources of the pollutants. Factor analysis (FA) is considered to be unbiased tools in the analysis of water quality and to derive meaningful information (Vega et al., 1998; Bengraine and Marhaba, 2003). In FA, variables such as EC, $\mathrm{COD}, \mathrm{H}_{2} \mathrm{SiO}_{4}$, $\mathrm{HCO}_{3}$, and $\mathrm{PO}_{4}$ contributed significantly along the factor one whereas variable such as $\mathrm{NO}_{3}$ contributed significantly in factor two. The strong negative loading was contributed by DO in factor two. Factor 1 loading were highest for EC, COD, H2SiO4, HCO3, and PO4 and these elements were significantly correlated with each other, this shows their common source. Factor loadings explained $79.71 \%$ of the total variance (Table 3). Factor one accounted for $57.88 \%$ and factor two explained $21.83 \%$ of the total variance. Eigen values of factor one and two were 10.99 and 4.14, respectively (Table 3).

Table 2: Correlation matrix of physico-chemical parameters of Karra River $(\mathbf{n}=16)$

\begin{tabular}{lcccccccc}
\hline & $\mathrm{pH}$ & $\mathrm{EC}$ & $\mathrm{DO}$ & $\mathrm{COD}$ & $\mathrm{H}_{2} \mathrm{SiO}_{4}$ & $\mathrm{HCO}_{3}$ & $\mathrm{NO}_{3}$ & $\mathrm{PO}_{4}$ \\
\hline $\mathrm{pH}$ & 1.00 & & & & & & & \\
$\mathrm{EC}$ & 0.01 & 1.00 & & & & & & \\
$\mathrm{DO}$ & 0.42 & $\mathbf{- 0 . 6 5}$ & 1.00 & & & & & \\
$\mathrm{COD}$ & -0.06 & $\mathbf{0 . 5 6}$ & $\mathbf{- 0 . 7 0}$ & 1.00 & & & & \\
$\mathrm{H}_{2} \mathrm{SiO}_{4}$ & -0.19 & $\mathbf{0 . 6 9}$ & $\mathbf{- 0 . 7 6}$ & $\mathbf{0 . 9 0}$ & 1.00 & & & \\
$\mathrm{HCO}_{3}$ & -0.05 & $\mathbf{0 . 6 6}$ & $\mathbf{- 0 . 6 0}$ & $\mathbf{0 . 5 8}$ & $\mathbf{0 . 6 9}$ & 1.00 & & \\
$\mathrm{NO}_{3}$ & -0.25 & 0.43 & $\mathbf{- 0 . 8 8}$ & $\mathbf{0 . 7 9}$ & $\mathbf{0 . 7 6}$ & 0.47 & 1.00 & \\
$\mathrm{PO}_{4}$ & -0.17 & $\mathbf{0 . 5 2}$ & $\mathbf{- 0 . 9 0}$ & $\mathbf{0 . 8 4}$ & $\mathbf{0 . 8 2}$ & $\mathbf{0 . 5 6}$ & $\mathbf{0 . 9 9}$ & 1.00 \\
\hline
\end{tabular}

Bold values indicate significant if $r>0.62$ then $p<0.01$; if $r>0.5-0.62$ then $p<0.05$ 
Table 3: Factor loadings of physico-chemical parameters (varimax rotation)

\begin{tabular}{ccc}
\hline Variable & Factor1 & Factor2 \\
\hline $\mathrm{pH}$ & 0.14 & -0.60 \\
$\mathrm{EC}$ & 0.95 & 0.25 \\
$\mathrm{DO}$ & -0.39 & -0.88 \\
$\mathrm{COD}$ & 0.90 & 0.19 \\
$\mathrm{H}_{4} \mathrm{SiO}_{4}$ & 0.85 & 0.40 \\
$\mathrm{HCO}_{3}$ & 0.74 & 0.51 \\
$\mathrm{NO}_{3}$ & 0.56 & 0.73 \\
$\mathrm{PO}_{4}$ & 0.86 & 0.49 \\
Eigen values & 10.99 & 4.15 \\
\% of total variance & 57.88 & 21.83 \\
Cumulative \% & 57.88 & 79.71 \\
\hline
\end{tabular}

\section{CONCLUSION}

River water pollution is increasingly widespread in Nepal. The present study is an attempt to detect changes in the water quality characteristics within the river system with respect to major physico-chemical parameters. The study reveals that there are additions of large quantities of industrial effluents into river. The dissolved oxygen content of the river water dropped from $8.47 \mathrm{mg} / \mathrm{L}$ to $0.71 \mathrm{mg} / \mathrm{L}$ on mixing with treated and untreated waste water from WWTP, HID while COD, nitrate and phosphate levels increased appreciably in the industrial belt at the sites IB5, IB8 IB9 and IB11. Results from stations can be attributed to various industrial effluents and also by the effluent of the waste water treatment plant in the industrial district. Although an improvement of water quality was observed in the downstream, probably as a result of self-purification and dilution effect. Effluent of waste water treatment plant did not meet effluent standard of Nepal and therefore, might pose a potential health hazard to the public as well as aquatic organism.

\section{ACKNOWLEDGEMENT}

The author is thankful to the University Grant Commission (UGC), Nepal for providing financial assistance to carry out this work.

\section{REFERENCES}

APHA., 1998. Standard Methods for the Examination of Water and Wastewater, eighteenth ed. American Public Health Association (APHA), American Water Works Association (AWWA) and Water Pollution Control Federation (WPCF), Washington, DC.

Bellos, D., Sawidis, T., 2005. Chemical Pollution Monitoring of the River Pinios (ThessaliaGreece). J. Environ. Manage. 76, 282-292.

Begum, A., Ramaiah, M., Khan, H. I., Veena, K., 2009. Heavy metal pollution and chemical profile of Cauvery River Water. E-J. Chem. 6, 47-52.

Bengraine, K., Marhaba, T.F., 2003. Using principal component analysis to monitor spatial and temporal changes in water quality. J. Hazar. Mater. 100, 179-195.

Carpenter, S.R., Caraco, N.F., Correll, D.L., Howarth, R.W., Sharpley, A.N., Smith, V.H., 1998. Nonpoint pollution of surface waters with phosphorus and nitrogen. Ecol.Appl. 8, 559-568.

Dunne, T., Leopold, L.B., 1978. Chemical characteristics of water. In: Dunne, T., Leopard, L.B (Eds), Water in Environmental Planning, W.H. Freeman and Company, New York, 727-766. 
Emongor, V., E. Kealotswe, I. Koorapetse, S. Sankwasa., S. Keikanetswe., 2005. Pollution indicator in Gaberone effluent. J. Appl. Sci. $5,147-150$.

Fernandez, H.M., Conti, L.F.C., Patchineelam, S.R., 1994. An assessment of the pollution of heavy metals in Jacarepagua basin, Rio de Janeiro, Brazil: a statistical approach. Environ. Tech. 15, 87-94.

Kannel, P.R., Lee, S., Kanel, S.R., Khan, P.S., 2007. Chemometric application in classification and assessment of monitoring locations of an urban river system. Anal. Chimica. Acta 582: 390-399.

Liao, S. W., Gau, H. S., Lai, W. L., Chen, J. J., Lee, C. G., 2007. Identification of pollution of Tapeng Lagoon from neighbouring rivers using multivariate statistical method. J. Envi ron. Manag. 88, 286-292.

Mukherjee,D., Chattopadhyay, M., Lahiri.S.C.,1993. Water quality of river Ganga (The Ganges) and some of its physio-chemicalproperties. The Environt. 13, 199-210.

Nouri, J., Karbassi, A. R., Mirkia, S., 2008. Environmental management of coastal regions in the Caspian Sea. Int. J. Environ. Sci. Tech. 5, 43-52.

Novotny, V., 2002. Water Quality: Diffusion pollution and Watershed Management. Wiley and Sons, New York.

Peterson , B.J., Deegan, L., Helfrich, J., Hobbie, J.E., Hullar, M.A.J., Moller, B., Ford, T.E., Hershey, A.E., Hiltner, A., Kipphut, G., Lock, M.A., Fiebig, D.M., McKinley, V.L., Miller, M.C., Vestal, R.J., Ventullo, R.M., Volk, G.S., 1993. Biological responses of a tundra river to fertilization. Ecol. 74, 653-672.
Peterson, B.J., Hobbie, J.E., Hershey, A.E., Lock, M.A., Ford, T.E., Vestal, R.J., McKinley, V.L., Hullar, M.A.J., Miller, M.C., Ventullo, R.M. Volk, G.S., 1985 Transformation of a tundra river from heterotrophy to autotrophy by addition of phosphorus. Sci. 229, 13831386.

Sarkar, S.K., Saha, M., Takada, H., Bhattacharya, A., Mishra, P., Bhattacharya, B., 2007. Water quality management in the lower stretch of the river Ganges, east coast of India: an approach through environmental education. J. Clean Prod. 15, 1559-1567.

Smith, V.H., Tilman, G.D., Nekola, J.C., 1999. Eutrophication: impacts of excess nutrient inputs on freshwater, marine, and terrestrial ecosystems. Environ. Pollut. 100, 179-19.

Ugochukwu, C.N.C., 2004. Effluent monitoring of an oil servicing company and its impact on the environment. Ajeam-Ragee, 8, 27-30.

Vega, M., Pardo, R., Barrado, E., Deban, L., 1998. Assessment of seasonal and polluting effects on the quality of river water by exploratory data analysis. Water Res. 32, 3581-3592.

Zhang, M.K., Wang, L.P., He, Z.L., 2007. Spatialandtemporalvariationofnitrogen exported by runoff from sandy agricultural soils. J. Environ. Sci. 19, 1086-1092.

Zhou, F., Huang, G.H., Guo, H.C., Zhang, W., Hao, Z.J., 2007. Spatio-temporal patterns and source apportionment of coastal water pollution in eastern Hong Kong. Water Res. 41, 3429-3439. 